\title{
HIGH-PROTEIN WEIGHT LOSS DIETS AND PURPORTED ADVERSE EFFECTS: WHERE IS THE EVIDENCE?
}

\author{
Anssi H. Manninen \\ Department of Physiology, Faculty of Medicine, University of Oulu, Finland. Sports Nutrition \\ Review Journal. 1(1):45-51, 2004. Address correspondence to anssi.manninen@oulu.fi.
}

Received March 1, 2004/Accepted May 9, 2004/Published (online):

\begin{abstract}
Results of several recent studies show that high-protein, low-carbohydrate weight loss diets indeed have their benefits. However, agencies such as the American Heart Association (AHA) have some concerns about possible health risks. The purpose of this review is to evaluate the scientific validity of AHA Nutrition Committee's statement on dietary protein and weight reduction (St. Jeor ST et al. Circulation 2001;104:1869-1874), which states: "Individuals who follow these [high-protein] diets are risk for ... potential cardiac, renal, bone, and liver abnormalities overall. Simply stated, there is no scientific evidence whatsoever that high-protein intake has adverse effects on liver function. Relative to renal function, there are no data in the scientific literature demonstrating that healthy kidneys are damaged by the increased demands of protein consumed in quantities 2-3 times above the Recommended Dietary Allowance (RDA). In contrast with the earlier hypothesis that highprotein intake promotes osteoporosis, some epidemiological studies found a positive association between protein intake and bone mineral density. Further, recent studies studies suggest, at least in the short term, that RDA for protein $(0.8 \mathrm{~g} / \mathrm{kg})$ does not support normal calcium homeostasis. Finally, a negative correlation has been shown between protein intake and systolic and diastolic blood pressures in several epidemiological surveys. In conclusion, there is little if any scientific evidence supporting above mentioned statement. Certainly, such public warnings should be based on a thorough analysis of the scientific literature, not unsubstantiated fears and misrepresentations. For individuals with normal renal function, the risks are minimal and must be balanced against the real and established risk of continued obesity. Sports Nutrition Review Journal. 1(1):45-51, 2004
\end{abstract}

Key Words: high-protein diets, adverse effects, American Heart Association

\section{INTRODUCTION}

Certainly, living organisms thrive best in the milieu and on the diet to which they were evolutionarily adopted. From all indications, Homo sapiens sapiens (anatomically modern humans) has remained biologically unchanged during at least the last 50,000 years. ${ }^{39}$ It was not until some 10,000 years ago that the transition from a roaming hunter and gatherer to a stationary farmer began. Consequently, our diet has become progressively more divergent from those of our ancient ancestors. The typical Paleolithic diet compared with the average modern American diet contained 3 to 4 times more protein. ${ }^{40}$

It is implausible that an animal that adapted to a high protein diet for 5 million years suddenly in 10,000 years becomes a predominant carbohydrate burner. Indeed, counter to the current U.S. Dietary Guidelines which promotes diet high in complex carbohydrates, recent clinical investigations support the efficacy of high-protein diets for weight loss/fat loss, as well as for improved insulin sensitivity and blood 
lipid profiles. Thus, the popularity of highprotein diets for weigh loss is unquestionable. However, there are always some concerns about high-protein diets.

In 2001, the American Heart Association (AHA) Nutrition Committee published statement on dietary protein and weight reduction. ${ }^{2}$ According to this statement, "Individuals who follow these [high-protein] diets are risk for... potential cardiac, renal, bone, and liver abnormalities overall. However, it should be noted that there is little if any evidence supporting these contentions. Thus, this review deals with the relationship between protein intake and renal function, bone health, blood pressure, heart disease and liver function. Also, effects of very-low carbohydrate diet on lean body mass loss are discussed.

\section{PROTEIN INTAKE AND RENAL FUNCTION}

Healthy individuals. Despite its role in nitrogen excretion, there are presently no data in the scientific literature demonstrating the healthy kidney will be damaged by the increased demands of protein consumed in quantities above the Recommended Dietary Allowance (RDA). Furthermore, real world examples support this contention since kidney problems are nonexistent in the bodybuilding community in which high-protein intake has been the norm for over half a century. ${ }^{3}$ Recently, Walser published comprehensive review on protein intake and renal function, which states: "it is clear that protein restriction does not prevent decline in renal function with age, and, in fact, is the major cause of that decline. A better way to prevent the decline would be to increase protein intake... there is no reason to restrict protein intake in healthy individuals in order to protect the kidney." 4

The study by Poortmans and Dellalieux investigated body-builders and other welltrained athletes with high- and mediumprotein intake, respectively. ${ }^{5}$ The athletes underwent a 7-day nutrition record analysis as well as blood sample and urine collection to determine the potential renal consequences of a high protein intake. The data revealed that despite higher plasma concentration of uric acid and calcium, bodybuilders had renal clearances of creatinine, urea, and albumin that were within the normal range. To conclude, it appears, at least in the short term, that protein intake under $2.8 \mathrm{~g} / \mathrm{kg}$ does not impair renal function in welltrained athletes.

More recently, Knight et al. determined whether protein intake influences the rate of renal function change in women over an 11-year period. ${ }^{32} 1624$ women enrolled in the Nurses' Health Study who were 42 to 68 years of age in 1989 and gave blood samples in 1989 and 2000. Ninety-eight percent of women were white, and $1 \%$ were African American. In multivariate linear regression analyses, high protein intake was not significantly associated with change in estimated glomerular filtration rate (GFR) in women with normal renal function (defined as an estimated GFR $\geq 80 \mathrm{~mL} / \mathrm{min}$ per $1.73 \mathrm{~m}^{2}$ ). Thus, the authors concluded that high protein intake does not seem to be associated with renal function decline in women with normal renal function. As pointed out by Lentine and Wrone $^{33}$, the generalizability of these findings is limited by sampling characteristics to white midadulthood, but this limitation is overshadowed by strong internal validity grounded in a large sample size, prospective outcomes ascertainment, and adjustment for multiple covariates.

Chronic Renal Failure. Historically, dietary protein restriction has been recommend as a therapeutic approach for delaying the progression of chronic renal failure (CRF). However, as pointed out by Ikizler, ${ }^{6}$ it is important to reassess the applicability of this approach. Indeed, the results of the largest randomised clinical trial, The Modification of Diet in Renal Disease (MDRD), did not demonstrate a benefit of dietary protein restriction on progression of renal disease. ${ }^{7}$ Further, CRF patients have been shown to require a protein intake of $1.4 \mathrm{~g} / \mathrm{kg} /$ day to 
maintain a positive or neutral nitrogen balance during nondialysis days, and even this intake may not be adequate for dialysis days. ${ }^{6}$

Diabetics. According to American Diabetes Association (ADA), there is no evidence to suggest that usual protein intake $(15-20 \%$ of total calories) should be modified if renal function is normal. ${ }^{8}$ The long-term effects of consuming $>20 \%$ of energy as protein on the development of nephropathy has not been determined, and therefore ADA nutritionists felt it may be prudent to avoid protein intakes $>20 \%$ of total daily energy. ${ }^{8}$ More recently, the metabolic effects of a high-protein diet were compared with those of the prototypical healthy (control) diet, which is currently recommended to persons with type 2 diabetes. ${ }^{31}$ The ratio of protein to carbohydrate to fat was 30:40:30 in the highprotein diet and 15:55:30 in the control diet. The high-protein diet resulted in a $40 \%$ decrease in the mean 24-h integrated glucose area response. Further, glycated hemoglobin decreased $0.8 \%$ and $0.3 \%$ after 5 weeks of the high-protein and control diets, respectively. Finally, fasting triacylglycerol was significantly lower after the high-protein diet than after the control diet. The authors concluded that a high-protein diet lowers blood glucose postprandially in persons with type 2 diabetes and improves overall glucose control. Cleary, longer-term studies are necessary to determine the total magnitude of response and possible adverse effects.

\section{PROTEIN INTAKE AND BONE HEALTH}

Increasing dietary protein increases urine calcium excretion such that for each $50 \mathrm{~g}$ increment of protein consumed, and extra 60 $\mathrm{mg}$ of urinary calcium is excreted. It follows that the higher the protein intake, the more urine calcium is lost and the more negative calcium balance becomes. Since $99 \%$ of the body's calcium is found in bone, one would hypothesize that high protein induced hypercalciuria would results in high bone resorption and increased prevalence of osteopenia or osteoporotic-related fractures.

However, the epidemiological and clinical data addressing this hypothesis are controversial. In fact, some epidemiological studies found a positive association between protein intake and bone mineral density (BMD)., ${ }^{9,37}$ Further, there is growing evidence that a low protein diet has a detrimental effect on bone. For example, Kerstetter et al. reported that in healthy young women, acute intakes of a low-protein $\operatorname{diet}(0.7 \mathrm{~g}$ protein $/ \mathrm{kg}$ ) decreased urinary calcium excretion with accompanied secondary hyperparathyroidism. ${ }^{10}$ The etiology of the secondary hyperparathyroidism is due, in part, to a significant reduction in intestinal calcium absorption during a low protein diet.

In a recent short-term intervention trial, Kerstetter et al. evaluated the effects of graded levels of dietary protein $(0.7,0.8,0.9$, and $1.0 \mathrm{~g}$ protein $/ \mathrm{kg}$ ) on calcium homeostasis. ${ }^{11}$ Secondary hyperparathyroidism developed by day 4 of the 0.7 and $0.8 \mathrm{~g}$ protein $/ \mathrm{kg}$ diets (due to the decreased intestinal calcium absorption), but not during the 0.9 or $1.0 \mathrm{~g}$ protein $/ \mathrm{kg}$ diets in eight young women. There were no significant differences in mean urinary calcium excretion over the relatively narrow range of dietary protein intakes studied, although the mean value with the $0.7-\mathrm{g} / \mathrm{kg}$ intake was lower than that with the $1.0 \mathrm{~g} / \mathrm{kg}$ intake by $0.25 \mathrm{mmol}(10 \mathrm{mg})$. According to authors of this study, the lack of change may be due to the small sample and the inherent variability in urinary calcium excretion. Similarly, when Giannini et al. restricted dietary protein to $0.8 \mathrm{~g}$ protein $/ \mathrm{kg}$, they observed an acute rise in serum parathyroid hormone $(\mathrm{PTH})$ in 18 middle-aged hypercalciuric adults. ${ }^{12}$ Taken together, both of studies suggest, at least in the short term, that the RDA for protein $(0.8 \mathrm{~g} / \mathrm{kg})$ does not support normal calcium homeostasis.

Furthermore, dietary protein increases circulating IGF-1, a growth factor that is thought to play an important role in bone formation. Indeed, several studies have examined the impact of protein supplementation in patients with recent hip fractures. For example, Schurch 
et al. reported that supplementation with $20 \mathrm{~g}$ protein/day for 6 months increased blood IGF-levels and reduced the rate of bone loss in the contralateral hip during the year after the fracture. ${ }^{28}$ More recently, the Cochranereview assessed the effects of nutritional interventions in elderly people recovering from hip fracture. ${ }^{41}$ Seventeen randomised trials involving 1266 participants were included. According to reviewers, the strongest evidence for the effectiveness of nutritional supplementation exists for oral protein and energy feeds, but the evidence is still weak.

Moreover, many of these early studies that demonstrated the calciuric effects of protein were limited by low subject numbers, methodological errors and the use of high doses of purified forms of protein. ${ }^{35}$ Indeed, the recent study Dawson-Hughes et al. did not confirm the perception that increased dietary protein results in urinary calcium loss. ${ }^{36}$ According to Dawson-Hughes et al., "The constellation of findings that meat supplements containing $55 \mathrm{~g} / \mathrm{d}$ protein, when exchanged for carbohydrate did not significantly increase urinary calcium excretion and were associated with higher levels of serum IGF-I and lower levels of the bone resorption marker, $N$-telopeptide, together with a lack of significant correlation of urinary $N$-telopeptide with urinary calcium excretion in the high protein group (in contrast to the low protein) point to the possibility that higher meat intake may potentially improve bone mass in many older men and women."

Finally, the cross-cultural and population studies that showed a positive association between animal-protein intake and hip fracture risk did not consider other lifestyle or dietary factors that may protect or increase the risk of fracture. ${ }^{35}$ It is of some interest that the author of the most cited paper favoring the earlier hypothesis that high-protein intake promotes osteoporosis no longer believes that protein is harmful to bone. ${ }^{34}$ In fact, he concluded that the balance of the evidence seems to indicate the opposite. ${ }^{34}$

\section{PROTEIN INTAKE AND BLOOD PRESSURE}

The AHA Nutrition Committee suggests that high-protein intake may increase blood pressure. However, there is no scientific evidence supporting this contention. In fact, a negative correlation has been shown between protein intake and systolic and diastolic blood pressures in several epidemiological surveys analyzed by Obarzanek et al. ${ }^{13}$ For example,

- Honolulu Heart Study. In this study of 6,406 Japanese-American men, a negative relationship was observed between systolic and diastolic blood pressures and the amount protein consumed. ${ }^{14}$

- Chinese Study. In this investigation of 2,672 adults men and women, a negative relationship was found between systolic pressure and the amount of animal protein consumed. ${ }^{15}$

- MRFIT Study. Based on 11,342 adult men, investigators observed a negative relationship between systolic blood pressure and the amount of total protein consumed. ${ }^{16}$

In both normotensive and hypertensive rats, increasing the dietary protein level enhances both urine and the amount of sodium excreted, although the mechanism behind these effects is unknown and still speculative. ${ }^{17}$ Interestingly, one study in human volunteers with a family history of hypertension has shown that a highprotein diet may counteract the adverse effects of excessive salt intake. ${ }^{18}$ For more information on protein intake and blood pressure, see the recent review by Debry. ${ }^{17}$

\section{PROTEIN INTAKE AND HEART DISEASE}

Recent findings by $\mathrm{Hu}$ et al. suggests that replacing carbohydrates with protein may be associated with a lower risk of ischemic heart disease. ${ }^{25}$ This result is consistent with evidence from metabolic studies that replacement of dietary carbohydrate with protein has favorable 
effect on plasma lipoprotein and lipid concentrations. However, because an increase in protein intake from animal products such as meats, dairy products, and eggs is often accompanied by increases in intakes of saturated fat and cholesterol, dietary advice to improve public health based on these findings should be made with caution. ${ }^{25}$

Recent novel approaches have shown that glucose and lipid intake may induce an increase in the generation of reactive oxygen species (ROS) and oxidative stress. For example, Mohanty et al. produced evidence that all three major macronutrients induce an increase in ROS generation. ${ }^{26}$ However, their data also show that different nutrients produce distinct patterns of stimulation of ROS generation after their intake. Of the three nutrients, glucose induced the greatest ROS generation, followed in decreasing order by fat (cream) and by protein (casein). The detriment of oxidative stress is that it may damage proteins and lipids, the latter through lipid peroxidation. Lipid peroxidation of LDL-C particles is an essential step in the development of atherosclerosis. ${ }^{27}$

\section{PROTEIN INTAKE AND LIVER FUNCTION}

AHA Nutrition Committee suggests that highprotein intake may have detrimental effects on liver function. However, there is no scientific evidence whatsoever supporting this contention. Protein is needed not only to promote liver tissue repair, but also to provide lipotropic agents such as methionine and choline for the conversion of fats to lipoprotein for removal from the liver, thus preventing fatty infiltration. ${ }^{20}$

Rodents fed very high protein intakes have been found to exhibit morphological changes in the liver mitochondria, which could be pathological. However, Jorda et al. reported that the liver responds to the high-protein diet by a proliferation of normally functioning mitochondria. ${ }^{24}$ Further, the branched-chain amino acids to aromatic amino acids ratio was also increased, indicating the absence of hepatic failure in these animals. The authors concluded that "the increased protein content of diet induced rapid increases in several characteristics of hepatocytes... The results presented here constitute a good example of how the hepatocyte adapts to a continuing metabolic stress."

Further, protein catabolism is increased in liver disease and may be exacerbated by inadequate protein in the diet. ${ }^{19}$ Unless there is encephalopathy (vide infra), the diet should provide high-quality protein in the amount of 1.5 to $2 \mathrm{~g} / \mathrm{kg} .{ }^{19}$ In alcoholic liver disease, a highcalorie, high-protein diet has been shown to improve hepatic function and reduce mortality. In one study, this was achieved by providing a regular diet plus supplements of $60 \mathrm{~g}$ /day of protein and $1600 \mathrm{kcal} /$ day for the first 30 days and followed by supplements of $45 \mathrm{~g}$ /day of protein and $1200 \mathrm{kcal} /$ day for the next 60 days. ${ }^{21}$

Finally, the role of protein restriction in patients with chronic hepatic encephalopathy (HE) has been questioned recently as the efficacy of protein withdrawal in patients with HE has never been subjected to a controlled trial. ${ }^{29}$ According to Srivastava et al., "the emphasis in the nutritional management of patients with $H E$ [hepatic encephalopathy] should not be on the reduction of protein intake. Instead, the goal should be to promote synthesis by making available ample amounts of amino acids, while instituting other measures to reverse the ongoing catabolism., 29

\section{EFFECTS OF VERY-LOW- CARBOHYDRATE DIET ON LEAN BODY MASS}

According to the AHA Nutrition Committee, "Some popular high-protein/low-carbohydrate diets limit carbohydrates to 10 to $20 \mathrm{~g} / \mathrm{d}$, which is one fifth of the minimum $100 \mathrm{~g} /$ day that is necessary to prevent loss of lean muscle tissue." Clearly, this is an incorrect statement since catabolism of lean body mass is reduced by ketones, which probably explains the 
preservation of lean tissue observed during very-low-carbohydrate diets.

For example, Volek et al. examined the effects of 6-week carbohydrate-restricted diet on total and regional body composition and the relationships with fasting hormones. ${ }^{22}$ Twelve healthy normal-weight men switched from their habitual diet ( $48 \%$ carbohydrate) to a carbohydrate-restricted diet $(8 \%$ carbohydrate) for 6 weeks and 8 men served as controls, consuming their normal diet. Subjects were encouraged to consume adequate dietary energy to maintain body mass during intervention.

Fat mass was significantly decreased $(-3.4 \mathrm{~kg})$ and lean body mass significantly increased $(+1.1 \mathrm{~kg})$ at week 6 . However, there were no significant changes in composition in the control group. The Authors concluded that a carbohydrate-restricted diet resulted in a significant reduction in fat mass and a concomitant increase in lean body mass in normal-weight men. They hypothesized that elevated $\beta$-hydroxybutyrate concentrations may have played a minor role in preventing catabolism of lean tissue but other anabolic hormones were likely involved (e.g., growth hormone).
Oddly, the AHA Nutrition Committee ignores the fact that energy restriction increases protein requirements. It has been know for about a half century that inadequate energy intake leads to increased protein needs, presumably because some of the protein normally used to synthesize both functional (enzymatic) and structural (tissue) protein is utilized for energy under these conditions. ${ }^{1}$ For example, Butterfield has shown that feeding as much as $2 \mathrm{~g}$ protein $/ \mathrm{kg} /$ day to men running 5 or 10 miles per day at $65 \%$ to $75 \%$ of their $\mathrm{VO}_{2 \max }$ is insufficient to maintain nitrogen balance when energy intake is inadequate by as little as $100 \mathrm{kcal} / \mathrm{day} .{ }^{30}$ Thus, when trying to lose weight, it is important to keep protein levels moderately high. The reduction in calories needed to lose weight should be at the expense of saturated fats and carbohydrates, not protein.

\section{CONCLUSION}

It is clear that the American Heart Association Nutrition Committee's statement on dietary protein and weight reduction contains misleading and incorrect information. Certainly, such public warnings should be based on a thorough analysis of the scientific literature, not unsubstantiated fears and misrepresentations. For individuals with normal renal function, the risks are minimal and must be balanced against the real and established risk of continued obesity. ${ }^{23}$

\section{REFERENCES}

1. Manninen AH. Protein metabolism in exercising humans with special reference to protein supplementation. Department of Physiology, Faculty of Medicine, University of Kuopio, Finland, 2002, pp. 1-164.

2. St. Jeor ST, Howard BV, Prewitt E et al. Dietary protein and weight reduction: A statement for health care professionals from the Nutrition Committee of the Council on Nutrition, Physical Activity, and Metabolism of the American Heart Association. Circulation 2001;104:1869-1874.

3. Street C. High-protein intake - Is it safe? In: Antonio J, Stout JR, eds. Sports Supplements. Philadelphia: Lippincott Williams \& Wilkins, 2001, pp. 311-312.

4. Walser M. Effects of protein intake on renal function and on the development of renal disease. In: The Role of Protein and Amino Acids in Sustaining and Enhancing Performance. Committee on Military Nutrition Research, Institute of Medicine. Washington, DC: National Academies Press, 1999, pp. 137-154.

5. Poortmans JR, Dellalieux O. Do regular high-protein diets have potential health risks on kidney function in athletes? Int J Sports Nutr 2000;10:28-38.

6. Ikizler TA. Nutrition support and management of renal disorders. In: Bronner, F. ed. Nutritional Aspects and Clinical Management of Chronic Disorders and Diseases. Boca Raton, FL: CRC Press, 2003, pp. 156-175.

7. Klahr S, Levey AS, Beck GJ et al. The effects of dietary protein restriction and blood-pressure control on the progression of chronic renal failure. N Engl J Med 1994;330:877-884.

8. American Diabetic Association. Evidence-based nutrition principles and recommendations for the treatment and prevention of diabetes and related complications. Diabetes Care 2002;25:S50-S60.

9. Cooper C, Atkinson EJ, Hensrud DD et al. Dietary protein intake and bone mass in women. Calcif Tissue Int 1996;58:320-325.

10. Kerstetter JE, O’Brien KO, Insogna KL. Dietary protein affects intestinal calcium absorption. Am J Clin Nutr 1998;68:859-865. 
11. Kerstetter JE, Svastislee C, Caseria D et al. A threshold for low-protein-diet-induced elevations in parathyroid hormone. $A m J$ Clin Nutr 2000;72:168-173.

12. Giannini S, Nobile M, Sartori L et al. Acute effects of moderate dietary protein restriction in patients with idiopathic hypercalciuria and calcium nephrolithiasis. Am J Clin Nutr 1999;69:267-271.

13. Obarzaneck E, Velletri PA, Cutler JA. Dietary protein and blood pressure. JAMA 1996;275:1598-1603.

14. Reed D, McGee D, Yano K, Hankin J. Diet, blood pressure, and multicollinearity. Hypertension 1985;7:405-410.

15. Zhou B, Wu X, Tao SQ. Dietary patterns in 10 groups and the relationship with blood pressure. Collaborative Study Group for Cardiovascular Diseases and their Risk Factors. Chin Med J 1989;102:257-261.

16. Stamler JS, Caggiuala A, Grandist GA. Relationship of dietary variables to blood pressure (BP) findings of the Multiple Risk Factors Intervention Study (MRFIT). Circulation 1992;85:867, Abstract 23.

17. Debry G. Data on hypertension. In: Dietary Proteins and Atherosclerosis. Boca Raton, FL: CRC Press, 2004, pp. 191-203.

18. Kuchel O. Differential catecholamine responses to protein intake in healthy and hypertensive subjects. Am $J$ Physiol 1998;R1164-R1173.

19. Navder KP, Lieber CS. Nutritional support in chronic disease of the gastrointestinal tract and the liver. In: Bronner, F. ed. Nutritional Aspects and Clinical Management of Chronic Disorders and Diseases. Boca Raton, FL: CRC Press, 2003, pp. 4568 .

20. Navder KP, Lieber CS. Nutrition and alcoholism. In: Bronner, F. ed. Nutritional Aspects and Clinical Management of Chronic Disorders and Diseases. Boca Raton, FL: CRC Press, 2003, pp. 307-320.

21. Mendellhall C, Moritz T, Roselle GA et al. A study of oral nutrition support with oxadrolone in malnourished patients with alcoholic hepatitis: results of a Department of Veterans Affairs Cooperative Study. Hepatology 1993;17:564-576.

22. Volek JS, Sharman MJ, Love DM et al. Body composition and hormonal responses to a carbohydrate-restricted diet. Metabolism 2002;51:864-870.

23. Feinman RD, Fine EJ. Thermodynamics and metabolic advantage of weight loss diets. Metab Synd Relat Disord 2003;1:209219.

24. Jorda A, Zaragosa R, Manuel P et al. Long-term high-protein diet induces biochemical and ultrastructural changes in rat liver mitochondria. Arch Biochem Biophys 1988;265:241-248

25. Hu FB, Stampfer MJ, Manson JA et al. Dietary protein and risk of ischemic heart disease in women. Am J Clin Nutr 1999;70:221-227.

26. Mohanty P, Ghanim H, Hamouda W et al. Both lipid and protein intake stimulates increased generation of reactive oxygen species by polymorphonuclear leukocytes and mononuclear cells. Am J Clin Nutr 2002;75:767-772.

27. Aljada A, Mohanty P, Dandona P. Lipids, carbohydrates, and heart disease. Metab Synd Relat Disord 2003;1:185-188.

28. Schurch MA, Rizzoli R, Slosman D et al. Protein supplements increase serum insulin-like growth factor-I levels and attenuate proximal femur bone loss in patients with recent hip fracture: A randomized, double-blind, placebo-controlled trial. Annals Internal Med 1998;128:801-809.

29. Srivastava N, Singh N, Joshi YK. Nutrition in management of hepatic encephalopathy. Trop Gastoenterol 2003;24:59-62.

30. Butterfield GE. Whole-body protein utilization in humans. Med Sci Sports Exer 1987;19:S167-S165.

31. Gannon MC, Nuttall FQ, Saeed A et al. An increase in dietary protein improves the blood glucose response in persons with type 2 diabetes. Am J Clin Nutr 2003;78:734-41.

32. Knight EL, Stampfer MJ, Hankinson SE et al. The impact of protein intake on renal function decline in women with normal renal function or mild renal insufficiency. Ann Intern Med 2003;138:460-7.

33. Lentine K, Wrone EM. New insights into protein intake and progression of renal disease. Curr Opin Nephrol Hypertens 2004;13:333-336

34. Heaney RP. Protein intake and bone health: the influence of belief systems on the conduct of nutritional science. Am J Clin Nutr 2001;73:5-6.

35. Ginty F. Dietary protein and bone health. Proc Nutr Soc 2003;62:867-76.

36. Dawson-Hughes B, Harris SS, Rasmussen H et al. Effect of dietary protein supplements on calcium excretion in healthy older men and women. J Clin Endocrinol Metab 2004;89:1169-73.

37. Geinoz G, Rapin CH, Rizzoli R et al. Relationship between bone mineral density and dietary intakes in the elderly. Osteoporos Int 1993;3:242-8.

38. Michaelsson K, Holmberg L, Mallmin H. Diet, bone mass, and osteocalcin: a cross-sectional study. Calcif Tissue Int 1995;57:86-93.

39. Åstrand P-O, Rodahl K, Dahl HA, Stromme SB. Our biological heritage. In: Textbook of Work Physiology. Champaign, IL: Human Kinetics, 2004, pp. 1-7.

40. O'Keefe JH, Cordain L. Cardiovascular disease resulting from a diet and lifestyle at odds with our Paleolithic genome: How to become a $21^{\text {st }}$-century hunter-gatherer. Mayo Clin Proc 2004;79:101-108.

41. Avenell A, Handoll H. Nutritional supplementation for hip fracture aftercare in the elderly. Cochrane Database Syst Rev 2004;1:CD001880. 